\title{
Rational and natural theology in Anne Conway's Principia
}

\author{
Jonathan Head* \\ School of Social, Political and Global Studies, Keele University, Newcastle-under-Lyme, UK \\ ${ }^{\star}$ Corresponding author. E-mail: j.m.head@keele.ac.uk
}

\begin{abstract}
This paper gives an account of the religious epistemology and theological working methods used in Anne Conway's Principia Philosophiae antiquissimae et recentissimae (1690). It is argued that the epistemic foundations of Conway's philosophical theology are rooted in a personal revelation of the existence and nature of God, which forms a framework through which the natural world can be approached and studied as creation. In this way, we can clarify both the place of Conway's work in the intellectual currents of the seventeenth century and various aspects of her metaphysical system, such as her account of creation.
\end{abstract}

Keywords: Anne Conway; creation; natural theology; rational theology; religious epistemology; revelation

A growing number of scholars have trained their attention on the philosophical theology of Anne Conway, as presented in her posthumous work, Principia Philosophiae antiquissimae et recentissimae (Principles of the Most Ancient and Modern Philosophy), first published in 1690. However, whilst the bulk of this scholarship has successfully served to illuminate many of her metaphysical and theological claims, little consideration has thus far been given to Conway's theological method, including her understanding of the sources of genuine religious and metaphysical knowledge, and the manner in which we are able to rationally reflect upon God and creation. This paper offers an introductory exploration of this theme in Conway's work, with a consideration of relevant passages from both the Principia and her correspondence. It is hoped that a more detailed account of these fundamental aspects of Conway's thought will lead to a deeper understanding of her theological system.

This paper is divided into three main sections. First, I consider the religious epistemology that underlies Conway's system, rooted in a foundational knowledge-claim regarding the existence and nature of God. Though Conway's epistemological assumptions in this regard are not referred to explicitly in the Principia, I argue that we can nevertheless reconstruct a model along both Platonist and Quaker lines, reflecting the primary influences upon her thought. As an illustration of this, I explore her account of suffering as a way of growth, both epistemically and spiritually.

In the following section, I focus on Conway's account of creation as an illustration of her theological method in practice. I argue that Conway's argumentation reveals a

(C) The Author(s), 2021. Published by Cambridge University Press. This is an Open Access article, distributed under the terms of the Creative Commons Attribution licence (http://creativecommons.org/licenses/by/4.0/), which permits unrestricted re-use, distribution, and reproduction in any medium, provided the original work is properly cited. 
rational theological method based on personal revelation, which coheres with the Platonist and Quaker influence upon her epistemology. Nevertheless, in the final section, I argue that Conway's appeal to observations concerning nature does show her adoption of a kind of natural theology that looks to patristic and medieval thinkers, and thus eschews a natural theological approach that was becoming increasingly in vogue in the late seventeenth century. We therefore see in Conway's theological method an aspect in which she looks to the Christian tradition to inform her approach and ultimately transcend the intellectual currents of her day.

\section{Religious epistemology and suffering}

By the time that Conway came to write the Principia in the final years of her life, she was a fresh convert to Quakerism, a Christian sect that was growing at the time and had a large presence in the area surrounding her residence at Ragley Hall in Warwickshire. We see the reflection of Quaker ideas, as well as the Platonism espoused by her philosophical mentor, Henry More, in the Principia: as an example of the former, we find the notion of Christ as an extended soul, which was a christology that was being discussed in Quaker intellectual circles of the time; ${ }^{1}$ and we will see in the next section that Conway's account of creation reflects deep-seated (Neo)platonic metaphysical assumptions. In order to reconstruct Conway's religious epistemology, and in particular the epistemological foundations of her philosophical theology, we would therefore do well to consider both Quaker and Platonic epistemology with a view to discerning whether hints of these ideas can be found in the Principia or her correspondence.

To begin with, we can note that Quaker religious epistemology then was largely based on the idea of a personal revelation grounded in the 'Christ within', the 'inner light' or 'light within'. The topic of the light within was a major part of Quaker thought at the time and features in correspondence between Conway and leading Quakers, such as William Penn. Around the time of Conway's convincement in 1675, we find Penn writing to Conway of the light within: 'My friend, we preach not our selves, but the light of Christ in the conscience, which is gods faithfull and true witness ... So dear friend, that though mayst retire thy mind to that tender spirit of truth which god hath sent into our hearts to convince us of sin, of righteousnesse, of judgement. ${ }^{2}$ The light within is posited in early Quaker thought as a personal cognisance of both the depravity of one's own sinful nature and the existence of a loving, just God through whom one can be purified. The acceptance of the light within by the individual, which is offered by God as a form of self-revelation in his grace, opens the individual up to a new kind of faith that fundamentally transforms both their knowledge and their character.

The impact of the inner light in the lives of Quakers is attested to in numerous texts from the period. As an example, we find an early prominent Quaker writer, Francis Howgill, speaking of the role of the inner light in his convincement and the attendant conversion of his moral character:

I was ignorant what the first principle of true religion was: but as I turned my mind within to the light of Jesus Christ wherewith I was enlightened ... I saw it

\footnotetext{
${ }^{1}$ See Anne Conway, Principles of the Most Ancient and Modern Philosophy, trans. and ed. Allison P. Coudert and Taylor Corse (Cambridge: CUP, 1996), 5.6; p. 27.

${ }^{2}$ The Conway Letters: The Correspondence of Anne, Viscountess Conway, Henry More and their Friends, 1642-1684, ed. Marjorie Hope Nicolson and Sarah Hutton (Oxford: OUP, 1992), p. 402.
} 
was the true and faithful witness of Christ Jesus, and then my eyes was opened, and all things was brought to remembrance that ever I had done ... in all that I ever did, I saw that it was in the accursed nature, and then something in me cried, Just and true is his judgement, my mouth was stopped, something rejoiced ... and as I did give up all to the Judgement, the captive came forth out of prison and rejoiced, and my heart was filled with joy ... and the new man was made. ${ }^{3}$

In the Quaker theological framework, espoused in this text and others, the inner light provides a foundational personal revelation that has both a transformative epistemic and moral impact upon the individual. All other aspects of religious life, including reflections upon scripture and the wonders of nature, are to be approached through the prism of this foundational revelation. Given that an experience of the inner light in such a manner was widely believed in the Quaker community at the time to be a prerequisite of true convincement, it is highly likely that Conway believed herself to have had such an experience. Thus, given that Conway was writing the Principia in the years following her convincement, we can be confident that she understood her own theological thought as grounded in precisely this kind of personal revelation affirmed by Quakers.

The supposition that Conway found such a theological approach amenable to her thought is strengthened by noting that the Quaker approach is similar to that found in another prominent strand of influence on her work. A complementary model for religious epistemology is offered by the Christian Platonist tradition, as found in the work of Conway's philosophical mentor, Henry More. The idea of a personal revelation is also prevalent in the work of the Cambridge Platonists, who included More in their number, insofar as one is able to gain religious knowledge of acquaintance through moral and spiritual growth. As Paul Avis explains, the Cambridge Platonists offered an account of reason that portrayed it as a powerful faculty that could use different epistemic resources to legitimately reflect on wide-ranging theological and philosophical issues:

reason was the image of God in humankind, 'the candle of the Lord', not a searchlight but an instrument and the best that we have ... [Their] concept of reason was not merely analytical, but infused with moral and mystical intuition, the whole person reasoning. Its sphere was the whole world. ${ }^{4}$

This semi-mystical faculty that manifested the intimate relation between God and the individual was the prism through which true believers could reflect upon nature and the teachings of the church, in order to reinforce and deepen faith and the understanding of creation.

As part of this Platonist approach, the individual could strengthen their rational faculty through moral reform. The idea was that, by engaging in moral development, and thereby becoming progressively more God-like, we are able to understand something of the nature of God within ourselves. As an example, More claims that one could be legitimately convinced of the immortality of the soul through the revelatory function of moral purification: 'our most palpable evidence of the soul's immortality is from an

\footnotetext{
${ }^{3}$ Francis Howgill, The Inheritance of Jacob Discovered (London: G. Calvert, 1656), pp. 11-13.

${ }^{4}$ Paul Avis, In Search of Authority: Anglican Theological Method from the Reformation to the Enlightenment (London: Bloomsbury, 2014), p. 174.
} 
inward sense, and this inward sense is kept alive the best by devotion and purity, by freedom from worldly care and sorrow, and the grosser pleasures of the body ${ }^{5}$. We can see this epistemic model as postulating a kind of knowledge by acquaintance of God: by becoming more God-like within ourselves, we learn more about God. So, as we become more morally pure, we are able to deepen our understanding of the perfect goodness of God. On this view, ontological, moral and epistemic progress are correlated, as progress towards God in one respect results in development in the others.

In the Principia, we find suffering being given a crucial role in the process by which creatures can become closer to God and thus gain religious knowledge. Conway sees suffering as both physically and morally purifying, releasing us from our fallen state, in which we have become distant from God in terms of our spirituality and moral disposition:

all pain and torment stimulates the life or spirit existing in everything which suffers. As we see from constant experience and as reason teaches us, this must necessarily happen because through pain and suffering whatever grossness or crassness is contracted by the spirit or body is diminished; and so the spirit imprisoned in such grossness or crassness is set free and becomes more spiritual. ${ }^{6}$

The purifying effect of suffering brings us ontologically closer to the infinite spirit that is God, and thus, given Conway's Platonist framework of knowledge by acquaintance, we gain increased understanding of God as a corollary of this process.

There is good reason to think that this how Conway viewed the effects of the ill-health that dogged her throughout her adult life. ${ }^{7}$ Allusions to a connection between bodily suffering and religious insight are found throughout her correspondence, ${ }^{8}$ with a note made by Henry More after Conway's death being particularly suggestive in this manner:

I perceive, and bless God for it, that my Lady Conway was my Lady Conway to her Last Breath; the greatest example of Patience and Presence of Mind, in highest Extremities of Pain and Affliction, that we shall easily meet with: Scarce anything to be found like her, since the Primitive Times of the Church. Of her Supernatural Comforts and Refreshments after some of her greatest Agonies and Conflicts, and of her strange Pre-visions of things future, I might here also make mention. ${ }^{9}$

We see here a clear connection posited by More between Conway's sustained experience of great suffering and mystical religious insight. Though the evidence is not conclusive, given that Conway's thought was greatly influenced by More, there is therefore a strong reason to suppose that she saw her own experience of suffering as bringing her closer to God, and thus as giving her a stronger epistemic basis from which to consider the theological and philosophical topics covered in the Principia. In this regard, it is also

\footnotetext{
${ }^{5}$ Henry More, Philosophical Poems (Cambridge: R. Daniel, 1647), preface to the 2nd edn, B4.

${ }^{6}$ Conway, Principles, 7.1 ; p. 43.

${ }^{7}$ Conway suffered from frequent, intense headaches, among other ailments.

${ }^{8}$ See e.g. More's reference to Conway's ill body as a 'holy Temple, an hallowed edifice for your soul to work in' (The Conway Letters, p. 337), in contrast to a healthy body, in which believers are easily led astray in their quest to find God.

${ }^{9}$ Quoted in Richard Ward, The Life of Henry More (Dordrecht: Kluwer, 2000), p. 126.
} 
noteworthy that the Principia was written as her illness reached its peak in the final years of her life. We therefore have good reason to believe that Conway viewed her own theological method as grounded in the kind of personal revelation posited in both the Quaker and Platonist epistemological traditions. In the Principia, Conway uses this epistemic foundation to construct both a rational and natural theology, as we shall see in the following sections.

\section{Rational theology and creation}

Conway's rational theological method can be clearly seen in action in the first two chapters of the Principia. Chapter I offers an account of the nature of the triune God, whilst chapter II proposes Conway's theory of creation. The book begins with the statement, 'God is spirit, light, and life, infinitely wise, good, just, strong, all-knowing, all-powerful, the creator and maker of all things visible and invisible. ${ }^{10}$ On the basis of this list of God's essential attributes, Conway proceeds to construct a rational theology that includes a theory of creation, a christology, a theology of the Holy Spirit and an account of the nature of divine freedom. To illustrate Conway's rational theological method, I will focus on her argument for the infinite duration of creation, stretching both into the past and the future, and by implication against a first moment of creation.

Conway bases her argument for the infinite duration of creation on the revelation of the infinite goodness of God. An infinitely good being, Conway argues, would wish to spread his goodness as far as he is able, and he can do this by creating other good beings. However, God cannot do this by creating other gods, as there can be only one ground of all life in the universe (again, something revealed in the initial list of divine attributes). So, in line with his divine goodness, God must create as many beings as possible who can share in his goodness but will inevitably fall short of his goodness to some extent. With regard to the question of the duration of creation, there are three possibilities that could be the case: (1) time could stretch finitely into the past and finitely into the future, (2) the universe began a finite number of years ago, but will stretch infinitely into the future, or (3) the duration of the universe stretches infinitely both into the past and into the future. The question we must consider, Conway argues, is which of these options allows God to spread his goodness as much as he is able and create as many beings as possible. As far as Conway is concerned, the answer is clearly that of the infinite duration of the universe:

it necessarily follows that he gave being to creatures from time everlasting or time without number, for otherwise the goodness communicated by God, which is his essential attribute, would indeed be finite and could be then numbered in terms of years. Nothing is more absurd. ${ }^{11}$

Thus, on the basis of the revelation of the infinite goodness of God, we can rationally deduce the infinite duration of the universe, apart from any empirical observations on the matter: 'Since he could have created worlds or creatures from time immemorial, before the year six thousand or sixty thousand or six hundred thousand, it follows that he has done this.' ${ }^{, 2}$

\footnotetext{
${ }^{10}$ Conway, Principles, 1.1 ; p. 9.

${ }^{11}$ Ibid., 2.4; p. 13.

${ }^{12}$ Ibid., 3.3 ; p. 16.
} 
Also, as part of her rational theology, Conway not only thinks that we can deduce the infinite time of creation, but also that an infinite number of beings have been created. Again, the revelation of God's perfect goodness, and the deduction that he would wish to create as much as possible, leads to the question of whether this would result in a finite or an infinite number of created beings. There seems to be no obvious contradiction in the idea of the creation of an infinite number of beings and so it must be the case that an infinite number of beings has been created. As Conway states:

When these divine attributes have been duly considered, it also follows than an infinite of worlds or creatures was made by God. For since God is infinitely powerful, there can be no number of creatures to which he could not add more. And, as has now been proven, he does as much as he can ... Thus it clearly follows that his creatures are infinite and created in an infinity of ways, so that they cannot be bounded or limited by number or measure. ${ }^{13}$

As we can see, Conway has a view of reason as an effective faculty for reflecting upon God's revelation and constructing a rational theology. It seems that, without having to engage with our observations concerning nature, we can come to wide-ranging theological and metaphysical truths that reach to the very fundamental features of creation, such as the nature of time and the number of created beings and worlds. This approach fits with the Cambridge Platonist framework considered earlier, which portrayed reason as a powerful, wide-ranging faculty that could legitimately reflect upon theological, moral and metaphysical questions, encompassing both creation and the divine. However, later in the Principia Conway moves on to engage with numerous reflections upon the world around us with a view to establishing theological insights, in the manner of a natural theology. So, the questions we will consider in the next section concern the nature of Conway's use of a natural theology, and how this connects with her rational theology and the epistemic foundations of her thought in personal revelation.

\section{The place of natural theology}

Following Conway's initial reflections on God's attributes, which lead to a rational theology (though one that is incomplete), the Principia moves on to a series of reflections upon features of nature that lead to further theological insight. The first point we can note with regard to Conway's natural theology is that she holds that nature has an intrinsic capacity to reveal something of the nature of God. Our capacity of being able to discern something of God through creation is not the result of a free decision by God; ${ }^{14}$ rather, it is the inevitable outcome of the manner in which God undertakes creative action. The root of Conway's views concerning the possibility of a natural theology lie in her distinction between communicable and incommunicable divine attributes: those divine attributes which creation can exemplify in an imperfect manner, and those which it cannot exemplify. As we see in the way that the attributes are distinguished, the difference is established on the basis of those which can be found in

\footnotetext{
${ }^{13}$ Ibid., 3.4; p. 16 .

${ }^{14}$ Such a view is held e.g. by Thomas F. Torrance, who argues that the revelatory capacity of nature is grounded in God's covenantal relationship with humankind: 'the whole of creation is formed to serve as the sphere of divine self-revelation, [and thus] it cannot be interpreted or understood out of itself. Thomas F. Torrance, The School of Faith (London: James Clarke, 1959), p. liii).
} 
degrees and those which cannot: 'The incommunicable [attributes] are that God is a being subsisting by himself, independent, immutable, absolutely infinite, and most perfect. The communicable attributes are that God is spirit, light, life, that he is good, holy, just, wise, etc. ${ }^{, 15}$ There are no degrees to being entirely self-subsistent, unchanging, or perfect, whilst there are degrees of goodness, justice, wisdom and so forth. Thus, creation can have the communicable divine attributes to a lesser extent than that enjoyed by God, but cannot share at all in the incommunicable divine attributes, as there is no lesser degree of these which a created being could exemplify.

Such a distinction is not particularly notable in itself; however, Conway claims that all of creation, as a matter of necessity, must exemplify all of the communicable divine attributes to at least some extent. In fact, God could not create in any other way than to create a world in which all of its beings exemplify his communicable attributes to at least some extent. So, there is nothing in creation that does not have some semblance of the communicable attributes of life or goodness, as God could not have created anything without these attributes:

For since God is infinitely good and communicates his goodness to all his creatures in infinite ways, so that there is no creature which does not receive something of his goodness, and this as fully as possible, and since the goodness of God is a living goodness, which possesses life, knowledge, love, and power, which he communicates to his creatures, how can any dead thing proceed from him or be created by him, such as mere body or matter[?]. ${ }^{16}$

Underlying these assumptions concerning the character of God's creative activity is a Neoplatonist causal framework, according to which some essential aspects of the nature of the cause must be found in the effect. Following the notion of Forms set out by Plato, ${ }^{17}$ realities at ontologically lower levels must imperfectly reflect those more perfect objects at higher levels of reality (so, for example, the landscape in front of me is beautiful only insofar as it imperfectly reflects the perfect Form of Beauty). In the Christian Platonic framework that Conway espouses, creation is taken to necessarily reflect the nature of God in certain essential aspects, which are the communicable divine attributes. Conway thus states that all of 'God's creatures, insofar as they are creatures, must be like their creator' in exemplifying all of the communicable attributes. ${ }^{18}$

What is particularly important for our purposes here, with regard to Conway's Christian Platonist account of creation, is the claim that God could only have created in such a manner. Though God is a free agent, God does not have indifference of the will, in the sense that he has a genuine choice between different courses of action. ${ }^{19}$ Given God's nature, there is only one way in which God can freely act, and thus in his creative action, 'God was not indifferent about whether or not to give being to creatures, but he made them from an inner impulse of his divine goodness and wisdom. ${ }^{20}$ As

\footnotetext{
${ }^{15}$ Conway, Principles, $7.2 ;$ p. 45.

${ }^{16}$ Ibid., 7.2; pp. 44-5.

${ }^{17}$ See Plato, The Republic (Harmondsworth: Penguin, 1974), 502c-511e; pp. 299-316.

${ }^{18}$ Conway, Principles, 7.2; p. 45.

${ }^{19}$ Ibid., 3.1; p. 15.

${ }^{20}$ Ibid., 3.3; p. 16. Further details regarding Conway's theory of divine freedom can be found in Jonathan Head, The Philosophy of Anne Conway: God, Creation and the Nature of Time (London: Bloomsbury Academic, 2020), pp. 133-50.
} 
Conway argues, 'God is infinitely good, loving, and bountiful' and so is bound to create a world teeming with life: 'In what way is it possible for that fountain [of goodness] not to flow perpetually and send forth living waters? For will not that ocean overflow in its perpetual emanation and continual flux for the production of creatures?'21 Thus, the reflections of the nature of God that we can find in creation is not something that is contingent upon the divine will, as God could not have chosen to create in any other way than which he did create. It is intrinsic to the nature of creation, given the Platonist framework that Conway is assuming, that it will inevitably manifest some aspects of the creator, albeit in an imperfect manner. The nature of the creative act guarantees that the communicable attributes of God will be found wherever we care to look, and thus natural theology can be used as a powerful tool that taps into the intrinsic capacity of nature to reveal something of the nature of God.

However, despite its potential scope and power, Conway's framework for natural theology does not allow it to be undertaken as an autonomous intellectual exercise, apart from any pre-existing religious knowledge or faith commitments. As we have seen, for Conway, discerning the existence and nature of God through nature involves the identification of the expression of communicable divine attributes in features of our experience. However, we cannot hope to make such an identification unless we already have an understanding of the divine attributes: if we do not know what the divine attributes are, then we will not know what to look for when we do any kind of natural theology. Just observing a pool of water that is teeming with fish and other lifeforms (an example used by Conway) does not by itself tell me anything about God; rather, it is only through my understanding of 'life' and 'goodness' as essential and communicable divine attributes that I can see the water as an expression of a good God who seeks to spread life as far as he is able. ${ }^{22}$ To take another example from Conway, the experience of love between parents and children does not add to our theological knowledge; however, within a preestablished theological framework, we are able to view such love as providing insights into the ultimate love given to us by God. ${ }^{23}$ The personal revelation of God as captured in the beginning statement of the Principia is therefore a necessary epistemic ground for natural theology: without an understanding of the divine attributes, it will inevitably be an unjustified epistemic exercise that ultimately misleads us in our quest to deepen our understanding of God and his creation.

In this regard, Conway's vision for natural theology is quite unlike that which was being increasingly proposed at the time of the writing of the Principia. The great advances made in the natural sciences, in particular the growing appreciation of the universal order of all things in creation, and a desire to promote individual freedom of enquiry, led to a new confidence in an autonomous discipline of natural theology that could offer us extensive theological knowledge apart from any divine self-revelation and traditional teachings of the church. However, as Alister McGrath emphasises, such an approach to natural theology was not how it had traditionally been practised; it had rather been an attempt to explore the resonance between a God whose existence was already held in faith and the structures of nature:

The existence of God was taken for granted. The purpose of natural theology was understood to relate to the question of the specific nature, not the existence of God

\footnotetext{
${ }^{21}$ Conway, Principles, 2.4 ; p. 13.

${ }^{22}$ Ibid., 6.6; p. 34 .

${ }^{23}$ Ibid., 7.3 ; p. 46.
} 
... [As] a matter of historical fact, natural theology is better to be understood as a demonstration, from the standpoint of faith, of the consonance between that faith and the structures of the world ... The search for order in nature is therefore not intended to demonstrate that God exists, but to reinforce the plausibility of an already existing belief. ${ }^{24}$

Natural theology, as practised in the Christian tradition prior to the seventeenth century, was largely undertaken from a standpoint of faith. It had one main aim: to add to the plausibility of a pre-existing religious belief system, partly by reinforcing the existence of God, but more often to clarify matters regarding the nature of God. We can see this traditional approach to natural theology in Conway's thought. As an example, whilst we may know that God is a loving God, this by itself does not necessarily entail how this love is expressed in the natural world. In order to understand how divine love has been manifested in creation, we have to rely upon our observations of nature, and we find a world teeming with living creatures that, Conway argues, have sympathetic, loving relations between each other: ${ }^{25}$ in other words, viewing nature in the right way, we see creation as ultimately filled with love. Further, once we see how God's love is expressed in creation (in such a munificent fashion), then we are thereby aided in grasping the depths of God's love for us, despite our fallen capacities and the disorder there is in the world.

So, we have a three-stage process in which religious knowledge can be developed through the medium of natural theology, as exemplified in the theological approach of Conway's Principia:

1. We begin with a personal revelation of the existence and nature of God (at least in broad terms) that furnishes us with a sufficient epistemic ground for a genuine faith-commitment.

2. We undertake observations of the natural world and note its general features, including its ordering and the interrelations between creatures.

3. We use our reflections upon the natural world to refine our understanding of the nature of God, and in particular, the relation between God and creation.

Also, to put it in a trinitarian context, the self-revelation of God gives us faith in the immanent Trinity, but natural theology is required to give us a deeper understanding of the economic Trinity. It is precisely this process that we see illustrated in Conway's Principia. We begin with a basic understanding of the nature of God, from which various metaphysical conclusions can be drawn (such as, for example, that the duration of creation must be infinite). Following this, we find Conway using a number of observations concerning the natural world (such as the plenitude of life and love between creatures) to deepen our understanding of both God and creation, as well as providing further confirmation of the existence of the former. Thus, the Principia presents us with a system that methodologically uses both rational and natural theology, with an ultimate epistemic foundation in God's self-revelation to each individual in the inner light.

One interpretive issue that clarifying Conway's theological methodology can help resolve is that concerning the nature of the arguments that she uses in the Principia when she connects empirical observations to religious topics. While some scholars

\footnotetext{
${ }^{24}$ Alister McGrath, Nature, vol. 1 of A Scientific Theology (Edinburgh: T\&T Clark, 2001), pp. 266-7.

${ }^{25}$ See Conway, Principles, 3.10; p. 20.
} 
have presented Conway's arguments in this regard as inferences to the best explanation (in other words, an argument of the form, 'Given the data that we have, which hypothesis out of the many available best fits that data?'), ${ }^{26}$ others have suggested that they might be best understood as arguments from conceivability. ${ }^{27}$ For example, take Conway's argument for the view that feelings of love are based on the recognition of apparent similarity. ${ }^{28}$ There are two ways in which we could construe how this argument works: first, if we are taking it as an inference to the best explanation, we can interpret Conway as arguing that, given our experiences of love, the most likely explanation for how love comes about is that it is on the basis of perceived similarity; or second, if we are taking it as an argument from conceivability, we interpret Conway as arguing that perceived similarity is the only conceivable basis for love, and so perceived similarity must be the basis for love. On the interpretation presented here, the debate between these two interpretations is ultimately inapposite, in that it pays insufficient attention to the methodological and epistemic framework that is being assumed by Conway here. Her arguments are not intended to be understood in the straightforward premises-conclusion format that we would expect of an autonomous natural theology. Rather, these observations made in the Principia are intended to illustrate the resonance between nature and creation, and deepen the faith-commitment and understanding of a believer who is already viewing the world from a particular theistic perspective. So, given the assumed theological and epistemic framework that underlies Conway's thought, we should not be thinking of these arguments as arguments from conceivability or as inferences to the best explanation, as ordinarily understood.

\section{Conclusion}

As we have seen, Conway uses a theological method that draws upon complementary approaches in Quakerism, Platonism and the wider Christian tradition. There is a place for natural theology in Conway's methodology, but its role in her work is fundamentally ancillary, in that it acts as a supplementary confirmation for the revelatory knowledge of the existence and nature of the triune God that is the bedrock of faith. The epistemic foundation of Conway's philosophical theology is in a personal revelation, which offers a framework for us to approach nature and discern the wisdom of God through it. In this way, we can see Conway as offering a vision of natural theology that harks back to pre-Enlightenment approaches. Conway's theological method also seems to offer a similar subordinate role to biblical revelation, in that scripture is approached as a created object (like any other) that can offer confirmation of religious truths (as seen throughout the Principia, where biblical references are occasionally made as post-hoc confirmation of various metaphysical claims). ${ }^{29}$

One of the advantages of considering Conway's theological method and epistemology is that it can aid us in gaining a deeper understanding both of how the

\footnotetext{
${ }^{26}$ An example of this kind of interpretation is offered by Jacqueline Broad, Women Philosophers of the Seventeenth Century (Cambridge: CUP, 2002), pp. 75-6.

${ }^{27}$ This interpretation has most prominently been suggested recently by Julia Borcherding, 'Loving the Body, Loving the Soul: Conway's Vitalist Critique of Cartesian and Morean Dualism', in Donald Rutherford (ed.), Oxford Studies in Early Modern Philosophy, vol. 9 (Oxford: OUP, 2019), p. 15.

${ }^{28}$ See Conway, Principles, 7.3 ; p. 47.

${ }^{29}$ See e.g. Conway's brief references to various biblical passages that seemingly allude to all created things having life. Conway, Principles, 8.7; p. 62.
} 
philosophical theology presented in the Principia fits into her intellectual context, including her response to various aspects of the Christian tradition, and how Conway's various theological and metaphysical claims are interlinked and refined alongside each other in a theoretical system. Given the preliminary nature of this study, these are certainly topics that scholars could benefit in exploring further in the literature, as we continue to explore Conway's fascinating work.

Cite this article: Head J (2021). Rational and natural theology in Anne Conway's Principia. Scottish Journal of Theology 74, 41-51. https://doi.org/10.1017/S0036930621000041 